\title{
The Research of the Bread Quality of High Nutritional Value Using Grain Mixtures
}

\author{
Zh.K. Nurgozhina ${ }^{1}$, D.A. Shansharova ${ }^{2}$, V. Sottnikova ${ }^{3}$, A.M. Saidov ${ }^{4}$, G.K. Yesseyeva ${ }^{5}$ \\ ${ }^{1}$ Almaty Technological University, Almaty, Republic of Kazakhstan, \\ ${ }^{2}$ Almaty Technological University, Almaty, Republic of Kazakhstan, \\ ${ }^{3}$ Mendel University, Czech Republic, Zemedelska \\ ${ }^{4}$ Kostanay State University A. Baitursynov, Kostanay, Republic of Kazakhstan, A. Baitursynov str
}

\begin{abstract}
The article discusses the aspects of bread fortification by adding a grain mixture to bread, as well as ensuring the microbiological safety of sprouted grains by using sourdoughs as a disinfecting factor. In the preparation of the grain mixture, the chemical composition was taken into account depending on the dosage of the constituent grains and oilseeds. The composition of the grain mixture included flax and sprouted grains of wheat, rape and amaranth. A control sample of bread was a sample of bread without sprouted grains and without sourdough, the second sample was a sample with sprouted grains without sourdough, the following samples were compared with these two samples: bread using thick rye sourdough and using flax sourdough. Organoleptic indicators were determined on the basis of hedonic studies; baking, microbiological, physicochemical indicators of the obtained breads were also determined. Of particular importance are the data on antioxidant activity and the content of polyunsaturated fatty acids. A study was also conducted on the quality of bread during storage after baking for 6,12 and 48 hours.
\end{abstract}

Based on the data obtained, conclusions were drawn. As a result of the studies, it was found that the use of grain mixtures increased the nutritional value of the obtained samples, and the use of flax sourdough further increased the organoleptic, microbiological and physicochemical properties of bread.

Keywords: sprouted grain, microbiological safety, grain mixtures, bread fortification

\section{INTRODUCTION}

Every year, the population's need for grain types of bread increases and becomes more and more urgent. In this article, we consider improving the technology of bread using grain mixtures to increase the nutritional value of the finished product.

Among grain crops, sprouted grains occupy a special place. At the moment, in Kazakhstan they are used little and mainly without scientific justification. In the process of germination, enzymes (especially the amylolytic complex) begin to activate and complex substances begin to break down to simple ones, which greatly helps the absorption of food. According to some reports, sprouted grains contain vitamins E 50 times, B6 10 times, 2-3 times more amino acids and 4-5 times more fatty acids. Sprouted grains also contain a large number of micro and macro elements $[1 ; 2]$. Grain-enriched bread is becoming more and more popular, which makes it necessary to study the effect of grains on the nutritional value of bread.

But in the production of bread with sprouted grains there are several nuances. So, to obtain a balanced bread that can give all vitamins and other elements, long germination is unacceptable and grain seedlings of a certain length are also unacceptable [3]. Germination of ripe wheat grain for more than 3 days leads to a decrease and weakening of gluten and a decrease in its hydration ability [4; 5]. In addition, there is a microbiological aspect. So, according to some researchers, 1 gram of freshly harvested grain contains from a thousand to several million bacteria, mainly up to $90 \%$ of bacteria, $5-7 \%$ of mold spores, etc [5].

In the process of germination, due to increased humidity and temperature, the grain becomes a favorable environment for the reproduction and sustainable development of microorganisms, this is unacceptable for preparation of foodstuff. Washing grain can reduce their content to $60 \%$ [6; 7].

But this method is not perfect enough, because there remains a sufficient number of microorganisms that can reduce the quality of the product, in addition, microorganisms can arise in the process of germination. There are various ways to reduce the contamination of microorganisms in the grain, for example, the cavitation method, microwave processing, the addition of various enzyme preparations, decoctions, electroactivated solutions [8].

But all these methods are costly and difficult to implement in a production environment. For this reason, we propose in this article a solution to this urgent problem.

Lactic acid, which is formed during fermentation of the sourdough, does not prevent the development of potato disease, which means that $B$. subtilis lowers acidity [9]. The emergence of antibacterial and anti-mold activity of lactic acid bacteria is caused by a whole complex of substances: carbon dioxide, lactic, caproic, acetic and phenyl lactic acids, diacetyl, hydrogen peroxide, reuterin, ring peptides, protein 
substances (bacteriocins), 3-hydroxy fatty acids [10].

In addition, the introduction of sourdough due to the enzymes contained in the sourdough, can disinfect the sprouted grain for further use in the production of bread [11]. This disinfecting effect of the use of sourdough will be considered in more detail in the article.

\section{MATERIALS AND METHODS}

Ready-made grain mixtures are convenient to use. If the composition of grain mixtures is balanced according to the content of nutrients, the final product with an increased food, biochemical value can be got. That is why the composition of grain mixtures is very important.

Oilseeds (especially flax and amaranth) are a rich source of proteins, lipids (especially polyunsaturated fatty acids) and are distinguished by their valuable mineral composition. A large consumption of amaranth flour bread can satisfy the daily requirement for protein, dietary fiber, ferrum and zinc, and polyunsaturated fatty acids in adults [12]. Wheat is characterized by a content of $12-15 \%$ protein and up to $75 \%$ carbohydrates, which is one of the best combinations of these substances in grain. Wheat is also rich in vitamins A and B. Rape is an oilseed crop characterized by excellent unpretentiousness and high yield, large areas of cultivation, which has been known since ancient times, the demand for rapeseed is increasing every year. Rapeseed is rich in proteins with a full amino acid composition, essential polyunsaturated fatty acids with a predominant content of linolenic acid, food fiber, minerals (calcium, phosphorus, magnesium, copper and manganese), which indicates the prospects of its use in the food industry [3]. Thus, flax seeds and sprouted grains of wheat, amaranth and rape were chosen as the object of study.

Due to the fact that sprouted grains contain a large amount of food fiber and other peripheral parts of the grain, standard fermentation and proofing processes become difficult. In order to prevent this, we used in our study wheat flour of the $1^{\text {st }}$ grade and various types of sourdoughs. Bread variants were prepared using thick rye sourdough and two different types of flax sourdough.

Studies were conducted to determine the organic, physicobiochemical and rheological indicators of bread with the addition of grain mixtures. We also investigated the microbiological indicators of bread with the addition of grain mixtures and the aspect of ensuring the microbiological safety of the use of sprouted grains in bread production. The studies were conducted in accordance with the requirements of certified standard organizations.

Preparatory operations with grain (including germination) and bread baking were carried out on the basis of scientific laboratories and technical centers of the Almaty Technological University (Republic of Kazakhstan) and Mendel University (Czech Republic).

Sprouted grains of wheat, amaranth, rape were obtained as a result of the following operations: washing the grain in clean drinking water, flushing the grain with $5 \%$ potassium permanganate solution for disinfection of sprouted grains, washing the grains again, preparing the grain for germination (soaking the grain in water) for 24 hours at a temperature of $20-22^{\circ} \mathrm{C}$. Then the germination was carried out at a temperature of $20-30^{\circ} \mathrm{C}$ and drying the sprouted grains to a moisture content of $13-14 \%$.

\section{RESULTS}

The grain mixture was composed for reasons of nutritional and nutraceutical value and human needs for various nutrients. The role of bakery products in meeting the needs of an adult in these vitamins is very significant. Due to the physicobiochemical properties of the grains themselves, it can be assumed that the grain mixture will be distinguished by a high content of polyunsaturated fatty acids, antioxidant activity, and fiber content $[15 ; 16]$. According to these criteria, preliminary formulations of the grain mixture were compiled and subsequently one recipe with a high content of nutrients was selected (Table 1, 2).

Table 1: Recipes of grain mixtures and their indicators of nutritional properties

\begin{tabular}{|c|c|c|c|c|}
\hline \multirow{2}{*}{ Name of raw material } & \multicolumn{4}{|c|}{ Recipe of grain mixture, \% } \\
\cline { 2 - 5 } & 1 & 2 & 3 & 4 \\
\hline Flax & 5 & 15 & 25 & 35 \\
\hline Sprouted wheat grains & 25 & 35 & 45 & 50 \\
\hline $\begin{array}{c}\text { Sprouted sorghum } \\
\text { grains }\end{array}$ & 35 & 25 & 20 & 10 \\
\hline $\begin{array}{c}\text { Sprouted amaranth } \\
\text { grains }\end{array}$ & 35 & 25 & 10 & 5 \\
\hline \multicolumn{2}{|c|}{} & & & \\
\hline
\end{tabular}

Table 2: Chemical indicators of grain mixtures

\begin{tabular}{|c|c|c|c|c|}
\hline \multirow{2}{*}{ Research indicators } & \multicolumn{4}{|c|}{ Recipe of grain mixture } \\
\cline { 2 - 5 } & 1 & 2 & 3 & 4 \\
\hline Protein, g & 10,1 & 10,6 & 12,8 & 13,4 \\
\hline Phosphorus, mg & 765,0 & 800,0 & 845,0 & 932,0 \\
\hline Zinc, mg & 10,9 & 12,2 & 13,1 & 15,2 \\
\hline Magnesium, mg & 301,7 & 315,0 & 335,0 & 350,0 \\
\hline Potassium, mg & 812,5 & 832,0 & 850,5 & 863,0 \\
\hline Vitamin B1, mg & 1,3 & 1,75 & 2,0 & 2,8 \\
\hline Vitamin B6, mg & 1,0 & 1,30 & 1,5 & 2,0 \\
\hline
\end{tabular}

Grain mixture numbers 3 and 4 turned out to be more preferable. In this case, the chemical composition of grain mixture No. 3 has a more preferred recipe and chemical composition. This sample has the most optimal performance compared to other samples. Thus, in a further study, the sample of grain mixture No. 3 was used.

The control variant of bread was a sample of bread without sprouted grains without sourdough, the second test sample 
was a sample with sprouted grains without sourdough, the following samples were compared with these two samples: bread using thick rye and flax sourdough (Table 3).

The recipe for bread products consisted of: $1^{\text {st }}$ grade wheat flour, medium rye flour, grain mixture, rye malt, pressed yeast, table salt, thick rye sourdough, flax sourdough, water.

The bread was baked in this way: the dough was kneaded for 3-4 minutes at a slow and 6-8 minutes at an average speed, the dough temperature was $28-30^{\circ} \mathrm{C}$, the dough was sweated for 10 minutes, the proofing was carried out for 45-60 minutes at a humidity of $80 \pm 5 \%$ and at a temperature of $30^{\circ} \mathrm{C}$, baking $200-230^{\circ} \mathrm{C}$ with a steam humidifier for 30 minutes. The calculation of water was taken from the calculation of $75 \%$ by weight of the grain mixture (1:1).

Judging by Tables 3 and 4, we can say that when adding a grain mixture from 5 to $25 \%$ of the total mass of wheat flour of the $1^{\text {st }}$ grade, despite the increase in lift depending on the content of the grain mixture, in general, the indicators are excellent. Judging by the results of Table 2, the most optimal variant for adding a grain mixture are variants number 2 of both types of bread with a $15 \%$ content of the grain mixture with a ratio of 60:35 and 60:25 to the mass of flour.

Depending on the differences in the ratio of components, there were significant differences in organoleptic indicators. Organoleptic indicators were determined on a hedonic scale using a nine-point questionnaire. To do this, the finished bread was cooled for 1 hour at room temperature, and then evaluated on a scale where 9 - the maximum score. Before starting the determination, bread was cut into thin slices $1,4 \mathrm{~cm}$ thick, two final slices were not used and sliced from the rest $4 \times 4 \mathrm{~cm}$ slices. A code was assigned for each type of bread.

Table 3: Recipe of bread with the addition of the grain mixture to the mass of flour

\begin{tabular}{|c|c|c|c|c|c|c|c|c|c|c|c|c|c|c|c|c|}
\hline \multirow{3}{*}{$\begin{array}{l}\text { Name of } \\
\text { raw } \\
\text { material }\end{array}$} & \multicolumn{16}{|c|}{ The quantity of input raw materials, $\%$ - by weight of flour (according to variants) } \\
\hline & \multicolumn{4}{|c|}{$\begin{array}{l}\text { With a ratio of flour } \\
60: 40\end{array}$} & \multicolumn{4}{|c|}{$\begin{array}{l}\text { With a ratio of flour } \\
70: 30\end{array}$} & \multicolumn{4}{|c|}{$\begin{array}{l}\text { With a ratio of flour } \\
80: 20\end{array}$} & \multicolumn{2}{|c|}{$\begin{array}{l}\text { Dough on thick rye } \\
\text { sourdough }\end{array}$} & \multicolumn{2}{|c|}{$\begin{array}{c}\text { Dough on flax } \\
\text { sourdough }\end{array}$} \\
\hline & $\mathrm{K}$ & 1 & 2 & 3 & K & 1 & 2 & 3 & K & 1 & 2 & 3 & Sourdough & Dough & Sourdough & Dough \\
\hline $\begin{array}{c}\text { Wheat flour } \\
\text { of the } 1^{\text {st }} \\
\text { grade }\end{array}$ & 40 & 35 & 25 & 15 & 30 & 25 & 15 & 5 & 20 & 15 & 5 & - & - & 40 & - & 35 \\
\hline $\begin{array}{l}\text { Medium } \\
\text { rye flour }\end{array}$ & 60 & 60 & 60 & 60 & 70 & 70 & 70 & 70 & 80 & 80 & 80 & 80 & - & 60 & - & 60 \\
\hline $\begin{array}{l}\text { Grain } \\
\text { mixture }\end{array}$ & - & 5 & 15 & 25 & - & 5 & 15 & 25 & - & 5 & 15 & 25 & - & - & - & - \\
\hline $\begin{array}{l}\text { Fermented } \\
\text { rye malt }\end{array}$ & 3,0 & 3,0 & 3,0 & 3,0 & 3,0 & 3,0 & 3,0 & 3,0 & 3,0 & 3,0 & 3,0 & 3,0 & - & - & - & - \\
\hline $\begin{array}{c}\text { Pressed } \\
\text { yeast }\end{array}$ & 1,0 & 1,0 & 1,0 & 1,0 & 1,0 & 1,0 & 1,0 & 1,0 & 1,0 & 1,0 & 1,0 & 1,0 & - & 1,0 & - & 1,0 \\
\hline Table salt & 1,5 & 1,5 & 1,5 & 1,5 & 1,5 & 1,5 & 1,5 & 1,5 & 1,5 & 1,5 & 1,5 & 1,5 & - & 1,5 & - & 1,5 \\
\hline Sourdough & - & 50 & 50 & 50 & - & 50 & 50 & 50 & - & 50 & 50 & 50 & - & - & - & - \\
\hline Water & \multicolumn{14}{|c|}{ According to the formula, based on the humidity of dough $45 \%$} & & \\
\hline $\begin{array}{c}\text { Rye flour } \\
\text { for } \\
\text { sourdough }\end{array}$ & - & - & - & - & - & - & - & - & - & - & - & - & 25 & - & - & - \\
\hline $\begin{array}{l}\text { Flax flour } \\
\text { for } \\
\text { sourdough }\end{array}$ & - & - & - & - & - & - & - & - & - & - & - & - & - & - & 15 & - \\
\hline
\end{tabular}

Table 4: Indicators of rye, wheat flour and dough

\begin{tabular}{|c|c|c|c|c|}
\hline \multirow{2}{*}{ Indicator } & \multicolumn{2}{|c|}{ Flour properties } & \multicolumn{2}{c|}{ Sourdough properties } \\
\cline { 2 - 5 } & medium rye & $\begin{array}{c}\text { wheat } 1 \\
\text { grade }\end{array}$ & thick rye & flax \\
\hline Humidity, \% & 12,0 & 14,0 & 49,5 & 51,3 \\
\hline Acidity, degree & 3,3 & 2,5 & 17,0 & 6,3 \\
\hline $\begin{array}{c}\text { Fall number, } \\
\text { seconds }\end{array}$ & 203,0 & 441,0 & - & - \\
\hline Lift, minutes & - & - & 31,0 & 37,0 \\
\hline
\end{tabular}

Participants in the amount of 20 people were not prepared and were selected according to the following criteria: age from 25 to 50 years old, non-smokers, no reported cases of food allergies, consuming wheat bread. Participants were asked to evaluate each type of bread for crumb chewing, taste, aroma, porosity structure, crumb color, crust color and overall acceptability. After evaluating each bread sample, participants were asked to rinse their mouths to more accurately evaluate the following samples. After the organoleptic evaluation of all samples by the participants in the experiment, the results were calculated in the arithmetic average and clearly expressed as 
International Journal of Engineering Research and Technology. ISSN 0974-3154, Volume 13, Number 11 (2020), pp. 3667-3674

(C) International Research Publication House. https://dx.doi.org/10.37624/IJERT/13.11.2020.3667-3674

Figure 1. Figure 2 is a visual photo of the obtained bread samples.

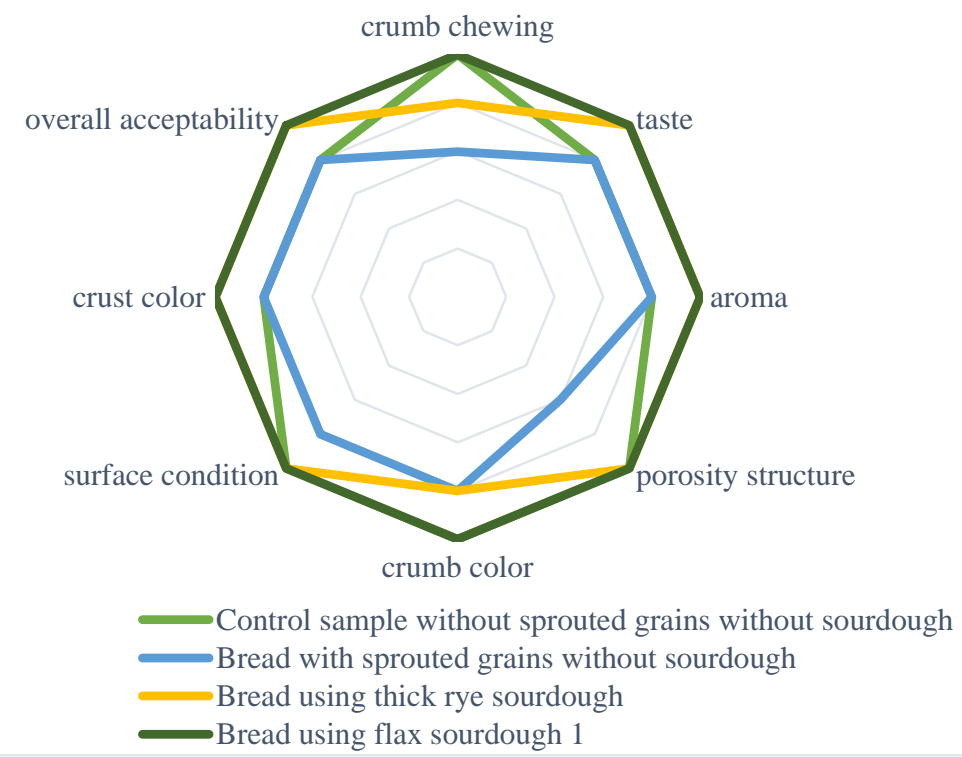

Figure 1: The effect of grain mixtures on organoleptic indicators introduced from bread samples from a mixture of wheat grade 1 and medium rye flour

The bread samples had the correct shape, the color of the crust was uniform, light brown, elastic crumb of a dark color with grain inclusions, the taste and aroma are pleasant, bread with a pleasant grain aroma. Samples of bread can be characterized as products with a good volume, regular shape and with a slightly convex crust. The presence in all samples of a small uniform porosity increases consumer qualities, and the presence of a soft, elastic crumb makes them even more attractive.

In general, all experimental bread samples had pleasant organoleptic characteristics. According to the results of a hedonic study, the samples of bread using flax sourdough have the best results. Bread using thick rye sourdough turned out to be less attractive, and the variant with sprouted grains with flax sourdough has the least optimal result.

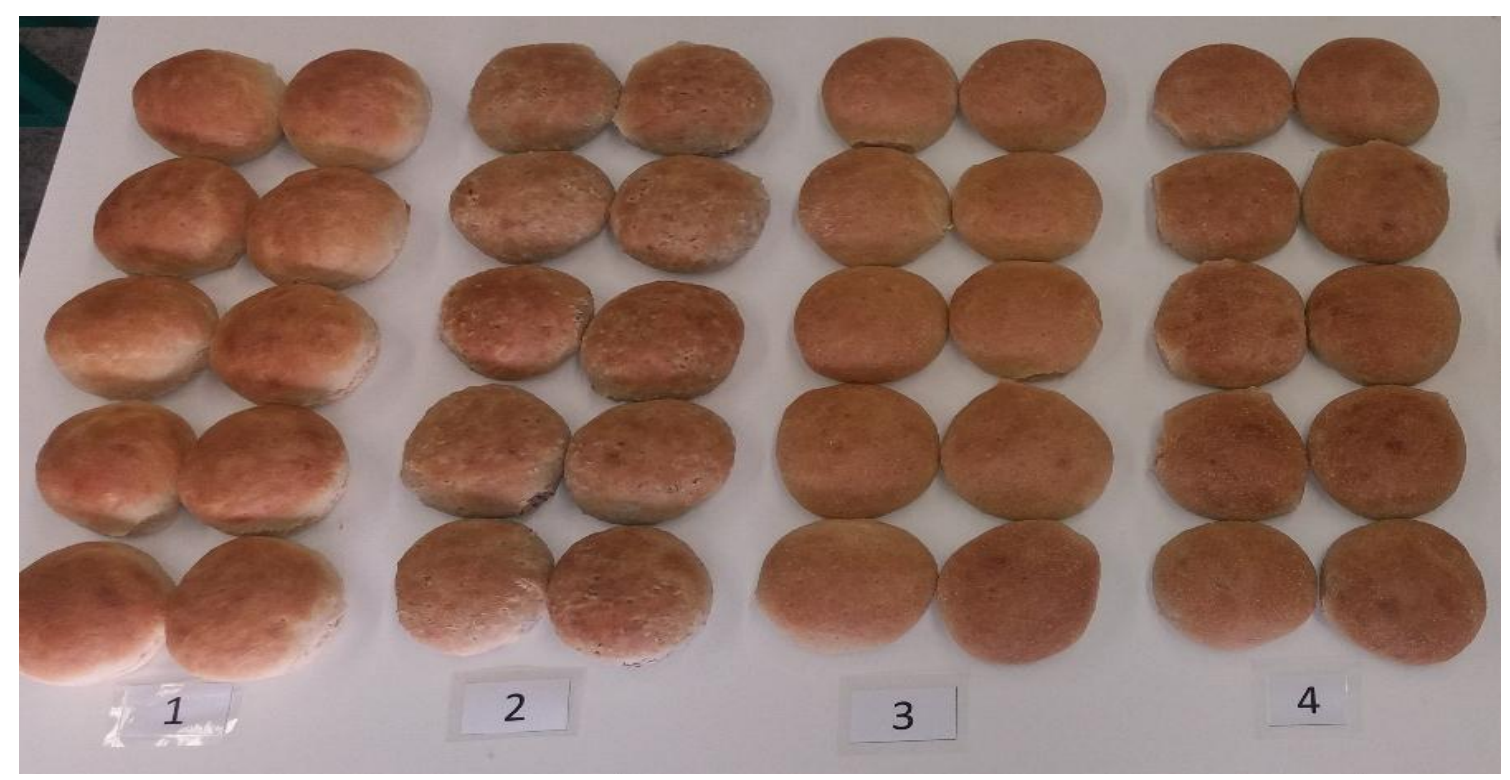

Figure 2: Obtained bread samples, where 1 - control, 2 - control sample with sprouted grains without sourdough, 3 - bread using thick rye sourdough, 4 - bread using flax sourdough 
International Journal of Engineering Research and Technology. ISSN 0974-3154, Volume 13, Number 11 (2020), pp. 3667-3674

(C) International Research Publication House. https://dx.doi.org/10.37624/IJERT/13.11.2020.3667-3674

Thus, it was revealed that the use of sourdough, especially flax, improves the quality of bread, however, bread with the addition of grain mixtures was very attractive and relevant for further research.

To determine the microbiological safety and, in general, the effect of sourdough on bread with the addition of sprouted grains, some studies were carried out (Tables 5, 6).

Table 5: Impact of sourdoughs on the microflora of bread with grain mixture

\begin{tabular}{|l|c|c|c|c|}
\hline \multicolumn{1}{|c|}{ Indicators } & $\begin{array}{c}\text { Control } \\
\text { sample } \\
\text { without } \\
\text { sprouted } \\
\text { grains without } \\
\text { sourdough }\end{array}$ & $\begin{array}{c}\text { Bread with } \\
\text { sprouted } \\
\text { grains } \\
\text { without } \\
\text { sourdough }\end{array}$ & $\begin{array}{c}\text { Bread using } \\
\text { thick rye } \\
\text { sourdough }\end{array}$ & $\begin{array}{c}\text { Bread using } \\
\text { flax } \\
\text { sourdough }\end{array}$ \\
\hline $\begin{array}{l}\text { Mesophilic anaerobic and } \\
\text { facultative microorganisms, } \\
\text { CFU/g }\end{array}$ & $3,2 \cdot 10^{4}$ & $4,5 \cdot 10^{4}$ & $3,0 \cdot 10^{3}$ & $2,0 \cdot 10^{3}$ \\
\hline Mold fungi, CFU/g & 28,0 & 40,0 & 29,0 & 23,0 \\
\hline E. coli bacteria, CFU/g & not found & not found & not found & not found \\
\hline Pathogens, Salmonella, g & not found & not found & not found & not found \\
\hline $\begin{array}{l}\text { Staphylococcus S.aureus, } \\
\text { g/cm }\end{array}$ & not found & not found & not found & not found \\
\hline
\end{tabular}

Due to the introduction of sourdoughs, the quantitative microflora content in the studied bread samples with the addition of sprouted grains significantly decreased. It should be noted that the introduction of flax sourdough in bread, greatly reduced the content of microorganisms.

It was also revealed that the addition of a grain mixture from sprouted grains without the use of sourdough increases the microbiological danger, while the addition of thick rye and flax sourdough slightly disinfects the bread. It was found that with an increase in the dosage of sourdough, the overall seediness of bread also slightly decreases.

Mold according to requirements may be contained in an amount of not more than $50 \mathrm{CFU} / \mathrm{g}$. The results obtained on the content of mold shows that bread using sprouted grains without sourdough again has a higher mold content.

The results of microbiological studies also showed that there are no pathogenic microorganisms of the Salmonella group, Staphylococcus, and E. coli bacteria in the bread. According to the requirements, these indicators should not be identified, as the study showed. Physico-chemical studies of the obtained bread samples were also carried out (Table 6).
Table 6: The ratio of the content of chemicals in breads per $100 \mathrm{~g}$ of bread and daily requirements, \%

\begin{tabular}{|c|c|c|c|c|}
\hline Indicators & $\begin{array}{c}\text { Control bread without } \\
\text { sprouted grains without } \\
\text { sourdough }\end{array}$ & $\begin{array}{c}\text { Bread with sprouted } \\
\text { grains without } \\
\text { sourdough }\end{array}$ & $\begin{array}{c}\text { Bread using } \\
\text { thick rye } \\
\text { sourdough }\end{array}$ & $\begin{array}{c}\text { Bread using } \\
\text { flax } \\
\text { sourdough }\end{array}$ \\
\hline Protein, g & $6,70 / 8,93$ & $10,31 / 13,73$ & $11,70 / 15,60$ & $11,31 / 15,06$ \\
\hline $\begin{array}{c}\text { Carbohydrates, } \\
\text { g }\end{array}$ & $32.0 / 8,76$ & $46.0 / 12,60$ & $47,6 / 13,04$ & $47,2 / 12,93$ \\
\hline Fat, g & $0,20 / 0,24$ & $0,80 / 0,96$ & $0,91 / 1,09$ & $0,93 / 1,12$ \\
\hline $\begin{array}{c}\text { Food fibers, g } \\
\text { Minerals, mg: } \\
\text { calcium } \\
\text { magnesium } \\
\text { phosphorus } \\
\text { ferrum }\end{array}$ & $1,30 / 4,33$ & $2,80 / 9,33$ & $3.21 / 10.66$ & $3.41 / 11.36$ \\
\hline $\begin{array}{c}\text { Vitamins, mg: } \\
\text { thiamine } \\
\text { riboflavin }\end{array}$ & $215,0 / 21.50$ & $257.0 / 25.70$ & $283.0 / 28.30$ & $288.0 / 28.80$ \\
\hline Antioxidant & $3.25 / 23.21$ & $3.58 / 25.57$ & $3.68 / 26.28$ & $3.69 / 26.35$ \\
\hline activity & $0,30 / 20$ & $0,51 / 34$ & $0,56 / 37,33$ & $0,58 / 38,66$ \\
\hline $\begin{array}{c}\text { Polyunsaturate } \\
\text { d fatty acid } \\
\text { content }\end{array}$ & $1,6 / 6,66$ & $0,18 / 10$ & $0,23 / 12,77$ & $0,24 / 13,33$ \\
\hline & not found & 3,58 & 4,02 & 4,68 \\
\hline & 35,6 & 35,8 & 41,6 \\
\hline
\end{tabular}

Judging by the results obtained, the sourdough slightly affects the chemical properties of bread, in contrast to the control sample without the use of sourdough and sprouted grains. For all indicators, the number of studied chemicals of all samples with the addition of sourdough increased compared to the control sample without the use of sourdoughs and sprouted grains up to $70 \%$. Compared with the control sample, an increase in the protein and phosphorus content in cereal breads using various sourdoughs was observed in the test samples.

Of particular note is the increase in antioxidant activity and the content of polyunsaturated fatty acids compared to the control sample. So, antioxidant activity increases in bread with sprouted grains by 2 times, in bread using thick rye sourdough by 2,3 times, and in bread without sourdough using flax sourdough by 2,6 times. The results of the study on the content of polyunsaturated fatty acids look more attractive, they were not found in the control sample, while in bread with sprouted grains their content increases by 35,6 times, in bread using thick rye sourdough by 35,8 times, and in bread without sourdough using flax sourdough by 41,6 times, this is due to the high content of polyunsaturated fatty acids in the grain mixture.

This is due to the content of flax seeds in flax sourdough, in contrast to thick rye sourdough, which gave an additional increase in antioxidant acidity and content of polyunsaturated fatty acids $[17 ; 18 ; 19 ; 20]$. Judging by the studies of the American Heart Association, it was recommended for people suffering from cardiovascular diseases, it is recommended to use omega-3 at a dose of $1 \mathrm{~g} /$ day, and for patients with high triglycerides, the dose should be increased to $2-4 \mathrm{~g} /$ day [21; $22 ; 23]$.

Thus, the consumption of $100 \mathrm{~g}$ of bread with the addition of flax sourdough satisfies the daily requirement of a healthy 
person for polyunsaturated fatty acids, calculated at $32 \%$.

An analysis of the data showed that bread samples are rich in minerals and vitamins, which are vital components of nutrition, ensuring the development and normal functioning of the human body. At the same time, bread using flax sourdough, according to the obtained organoleptic, physicochemical indicators, surpasses bread using thick rye sourdough.
Next, the changes occurring in bread samples during storage were investigated. The studied bread samples were stored at a temperature of $20 \pm 5^{\circ} \mathrm{C}$ and a relative humidity of $75 \pm 5 \%$. Evaluation of the quality of bread was carried out after 6, 24, 48 hours after baking. The dynamics of changes is presented in Figure 3. In the framework of the study, an organoleptic analysis of the degree of freshness was carried out using an eight-point scale, where 8 - completely fresh, 7 - fresh, 6 moderately fresh, 5 - slightly fresh, 4 - barely fresh, 3 moderately fresh, 2 - callous, 1 - completely callous.

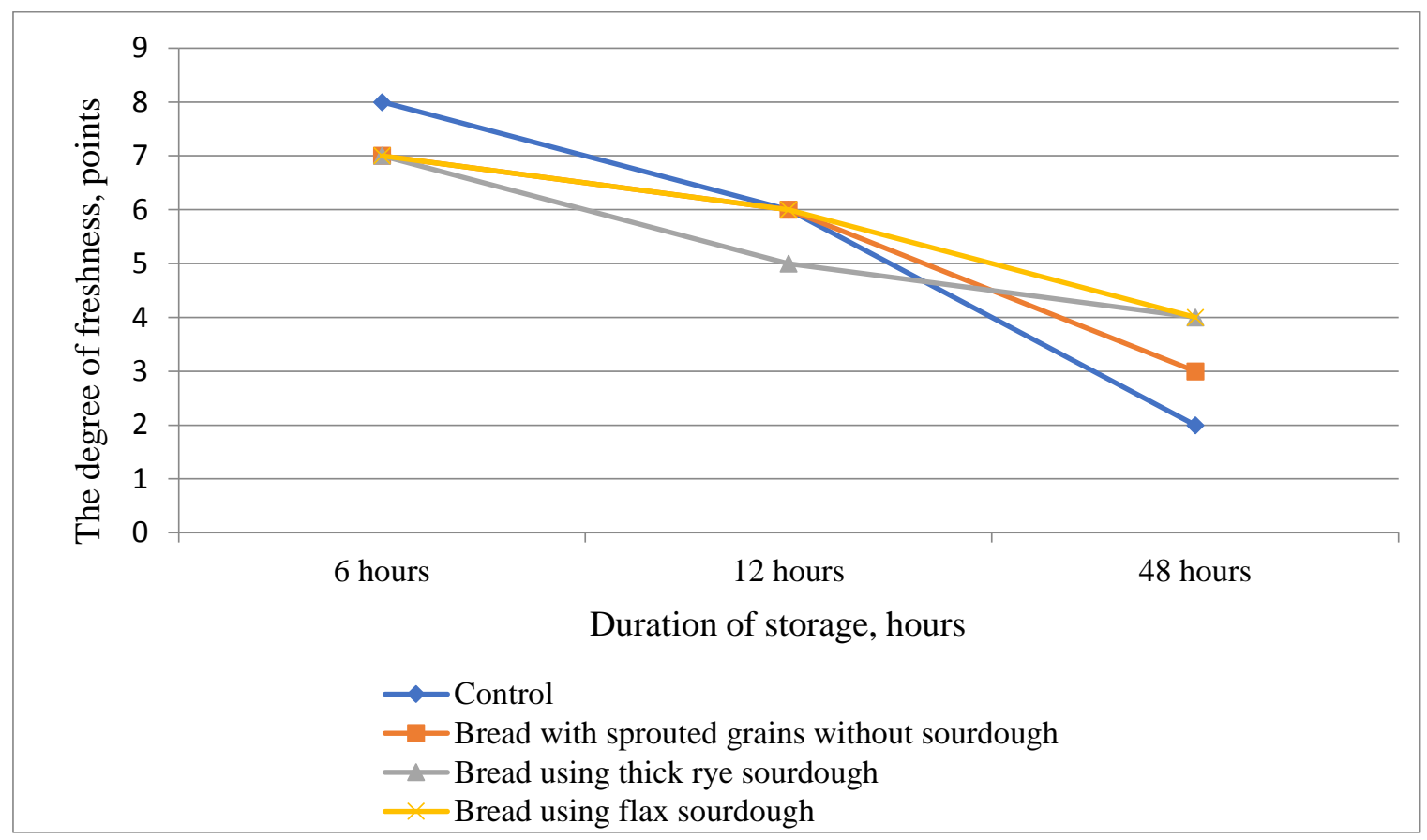

Figure 3: Changes in the freshness degree of the studied bread samples

The greatest difference was noted at the end of the study, when the control sample received 2 points, and bread using sourdoughs -4 points. This is due to the peculiarity of the recipes of different bread samples, especially the presence of sourdoughs and the presence of sprouted grains. After baking, all samples received the highest score, and a few hours after the end of the storage period, the readings of all samples amounted to 1 point.

The results obtained show that a change in the recipe and the use of sprouted grains and starter cultures can slow down the process of moisture loss, and hence the drying of bread during storage during the study time. Most intensively, these processes occur in the first 24 hours of storage.

\section{CONCLUSION}

The quality indicators of bread prepared using flax sourdough significantly differed from the control sample, namely, in specific volume and structure of porosity. According to organoleptic indicators, experimental samples of bread, compared with the control sample, were more attractive in appearance, state of porosity, crumb color, taste and aroma.

Based on the studies, the following conclusions are made. The nature of the influence of flax flour on the quality of bread made from a mixture of medium rye and wheat flour of I grade was studied. It was found that the introduction of a grain mixture in an amount of $5-25 \%$ of the total mass of flour affects the quality of bread. At the same time, physicochemical indicators of the quality of bread are reduced with an increase in the organoleptic characteristics of the finished products. It was established that the best quality characteristics were possessed by bread samples prepared with the addition of $15 \%$ flax flour.

It was experimentally shown that the best quality was observed when preparing bread from a mixture of medium rye and wheat flour of the 1st grade in a ratio of 60:25 and making flax flour as part of flax sourdough.

Also, according to the results of the studies, it can be argued that bread with the addition of flax yeast compares favorably with other samples not only in microbiological, but also in organoleptic, physico-chemical properties, as well as the ability to long-term storage. As a result of the studies, 
enriched bread with the addition of sprouted grains and flax sourdough was obtained.

In general, the technology of bread using sourdoughs is relevant for the modern world and offers great opportunities for enriching bread, expanding the assortment and ensuring the microbiological safety of grain bakery products, especially with the addition of sprouted grains.

\section{REFERENCES}

[1] Papadimitriou K., Zoumpopoulou G., Georgalaki M., Lexandraki V., Kazou Anastasiou R., Tsakalidou E.(2019). Innovations in Traditional Foods Woodhead Publishing, $339 \mathrm{p}$.

[2] Medvedev P.V., Fedotov V.A., Bochkareva I.A.(2016). Quality management of products of grain processing and grain products. Nauchniy gurnal NIU ITMO [Scientific journal of NIU ITMO], no. 1. pp. 61-69. (in Russian)

[3] Ačanski M., Agama-Acevedo E., Ahmed M.A., Akhtar S., Alonso-Domínguez R., Anyango J. O., Apea-Bah F. B., Arantes V.C., A. Arzani, M. F. Aslam, G. Barrera, E. (2019).Beckett etc. Flour and Breads and their Fortification in Health and Disease Prevention (Second Edition) P. 501

[4] Huzin F.K., Kanarkaya Z.A., Ivleva A.R., Gematdinova V.M. (2017).Perfection of technology of production of bakery products on the basis of crushed sprouted wheat grain. Vestnik VGUIT [Proceedings of VSUET]. Vol. 79. no. 1. pp. 178-187. (in Russian)

[5] Finnie S., Brovelli V., Nelson D. (2019).Sprouted Grains, Nutritional Value, Production and Applications 344 p.

[6] Suresh P.V.(2016). Sustainable valorization of seafood by products: Recovery of collagen and development of collagen-based novel functional food ingredients // Innovative Food Science \& Emerging technologies. № 37. P. 201-215.

[7] Sanna M., Fois S., Falchi G. , Campus M., Roggio T., Catzeddu P. (2019).Effect of liquid sourdough technology on the pre-biotic, texture, and sensory properties of a crispy flatbread Food Science and Biotechnology , Volume 28, Issue 3, pp 721-730

[8] MGhodki B., Dadlani G., MGhodki D., Chakraborty S.(2019). Functional whole wheat breads: Compelling internal architecture LWT Volume 108. Pages 301-309

[9] Tebben L., Shen Y., Li Y. (2018). Improvers and functional ingredients in whole wheat bread: A review of their effects on dough properties and bread quality Trends in Food Science \& Technology Volume 81, November . Pages 10-24

[10] Torbica A., Belović M., Tomić J.(2019). Novel breads of non-wheat flours, Food Chemistry Volume 282, Pages $134-140$

[11] Sinelnikova O.V.(2011). Improving the technological process and ensuring microbiological safety in the production of grain bread using wheat seedlings / Abstract. dis. for competition PhD. / Moscow, P.12

[12] Carmen K., Ramos I., Sanz-Ponce N., Monika C.(2019). Evaluation of technological and nutritional quality of bread enriched with amaranth flour/ // LWT in Press.

[13] Agro-cultural site of Kazakhstan https://kazakhzerno.net/373-raps/, accessed: 10/28/2019 (in Russian)

[14] Wang Q. (2017).Review on the processing characteristics of cereals and oilseeds and their processing suitability evaluation technology / Qiang Wang, Hong-zhi Liu, Ai-min Shi, Hui Hu, Li Liu, Li Wang, Hong-wei Yu/ Journal of Integrative Agriculture, Volume 16, Issue 12, December Pages 2886-2897

[15] Clément H., Prost C., Chiron H., Ducasse M.B., Valle G.D., Courcoux P., Onno B. (2018).The effect of organic wheat flour by-products on sourdough performances assessed by a multi-criteria approach Food Research International Vol. 106, April 2018, P. 981

[16] Sajdakowska M., Gębski J., Żakowska-Biemans S., Jeżewska-Zychowicz M. (2019)/ Willingness to eat bread with health benefits: habits, taste and health in bread choice Public Health Volume 167, February Pages 78-87

[17] Stone N.J., Robinson J.G., Lichtenstein A.H. et al(2013)..; American Col- lege of Cardiology/American Heart Association Task Force on Practice GuidelinesACC/AHA guideline on the treatment of blood cholesterol to reduce atherosclerotic cardiovascular risk in adults: a report of the American College of Cardiology/American Heart Association Task Force on Practice Guidelines // Circulation. 2014. V. 129. № 25. Suppl. 2. P. S1-4.

[18] Nurgozhina Zh.K., Kizatova M. Zh., Iskakova G.K., Nabieva Zh.S., Uvakasova G.T., Satvaldinova A.G.(2018). The role of the Omega grain mixture in the enrichment of bread with essential polyunsaturated fatty acids Polish Science Journal - Warsaw: Sp.zo.o. "iScienca", p.160166 (in Russian)

[19] Kizatova M.Zh., Pronina Yu.G., Nabieva Zh.S., Nurgozhina Zh.K., Gumarov B.(2019). Increase in Nutritional and Biological value of white bread with use of the grain mix "Omega-6" The Bulletin the National academy of Sciences of the Republic of Kazakhstan \#5, Almaty p70-77.

[20] Gökmen V., Ataç Mogol B., Lumaga R.B., Fogliano V., Kaplun Z., Shimoni (2011).Development of functional bread containing nanoencapsulated omega-3 fatty acids Journal of Food Engineering Volume 105, Issue 4, August Pages 585-591

[21] Piland D.K., Ohlfest M.(2008). Acceptance of Omega-3 Supplemented Quick Breads Utilizing Flaxseed Products, Walnuts, and Omega-3 Fatty Acid Containing Eggs Journal of the American Dietetic Association Volume 108, Issue 9, Supplement, September Page A55

[22] Iztayev A., Yakiyayeva M., Kulazhanov T., Kizatova M., 
International Journal of Engineering Research and Technology. ISSN 0974-3154, Volume 13, Number 11 (2020), pp. 3667-3674

(C) International Research Publication House. https://dx.doi.org/10.37624/IJERT/13.11.2020.3667-3674

Maemerov M., Stankevych G., Toxanbayeva B., Chakanova Z.(2018). Efficient mathematical models of ion-ozon cavitation treatment for long-term storage of grain legume crops Acta Technica CSAV (Ceskoslovensk Akademie Ved).

[23] Iztayev, A., Kulazhanov, T., Yakiyayeva, M., Maemerov, M., Iztayev, B., Mamayeva, L.(2018). The efficiency of ionocavitational processing and storage in the nitrogen medium of oilseeds Journal of Advanced Research in Dynamical and Control Systems. 